\title{
Symposium review: Colostrum management and calf nutrition for profitable and sustainable dairy farms*
}

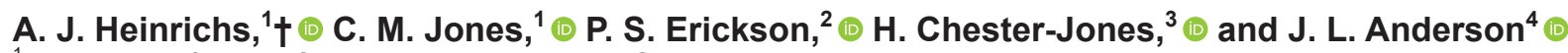 \\ ${ }^{1}$ Department of Animal Science, The Pennsylvania State University, University Park 16802 \\ ${ }^{2}$ Department of Agriculture, Nutrition, and Food Systems, University of New Hampshire, Durham 03824 \\ ${ }^{3}$ Southern Research and Outreach Center, University of Minnesota, Waseca 56093 \\ ${ }^{4}$ Dairy and Food Science Department, South Dakota State University, Brookings 57007
}

\begin{abstract}
Multistate dairy management research project NC2042, which is part of the National Institute of Food and Agriculture, has devoted an ongoing objective to calf and heifer nutrition and management. Within this objective, colostrum research has been a priority due to continued opportunities to improve this area on US dairy farms. Research has focused on heating colostrum to reduce bacterial populations and pathogens while increasing IgG absorption. Research also identified other proteins that are reduced when heating colostrum. Studies indicated an apparent upper limit to IgG absorption from colostrum fed to calves. Additional studies have shed light on absorption of IgG from colostrum replacers and evaluated the use of lactoferrin and sodium bicarbonate in both maternal colostrum and colostrum replacers. Milk replacer formulation, feeding strategies, and the effect of calfhood nutrition on future performance have also been researched. Finally, water quality and its effect on calves and heifers have been studied. This review focuses on research done by multistate research project NC-2042 member states in the area of colostrum and calf nutrition and management. Key words: dairy calf, colostrum, milk replacer
\end{abstract}

\section{HEAT TREATMENT OF COLOSTRUM}

Colostrum is a most important aspect of dairy calf health and management and is a critical item for all dairy farms to use. A survey of colostrum management practices (Kehoe et al., 2007b) showed that although colostrum composition on dairy farms in 2006 was

Received August 5, 2019.

Accepted October 11, 2019

*Presented as part of the Production, Management, and the Environment: Profitability and Sustainability Symposium at the ADSA Annual Meeting, Cincinnati, Ohio, June 2019.

†Corresponding author: ajh@psu.edu similar to that in previous years (Foley and Otterby, 1978), the variation found on Pennsylvania farms was extremely large. Several samples clearly were transition milk and not colostrum, with ranges of 2.0 to $26.5 \%$ fat, 7.1 to $22.6 \%$ protein, and 11.8 to $74.2 \%$ IgG observed (Kehoe et al., 2007b). The most troubling aspect of the survey was the bacterial analysis of colostrum samples (Houser et al., 2008), which showed very high coliform and standard plate counts in $51 \%$ of samples. This and the increased awareness of colostrum as a transmission pathway for Johnne's disease led to many studies related to heating colostrum. Elizondo-Salazar et al. (2010) and Godden et al. (2006) studied the time and temperature requirements for reducing bacteria numbers while preserving viscosity and IgG levels in colostrum. They concluded that $60^{\circ} \mathrm{C}$ and $30 \mathrm{~min}$ (ElizondoSalazar et al., 2010) to $60 \mathrm{~min}$ (Godden et al., 2006) of batch-process heating were optimal for colostrum. Heat treatment generally reduced colostrum IgG levels by approximately $5 \%$, but it was noted that blood IgG levels were markedly improved when feeding this product. It was determined that the apparent efficiency of absorption (AEA) of Ig was the key issue related to improved concentrations of IgG in calves (ElizondoSalazar and Heinrichs, 2009b). Several studies that followed were consistent in implicating lower bacterial populations in heat-treated colostrum as the underlying factor improving IgG absorption (Elizondo-Salazar and Heinrichs, 2009a; Gelsinger et al., 2014). A critical paper then proved that it was a reduction in bacteria and not some other element of the heat-treating process that was improving IgG absorption (Gelsinger et al., 2015). This study (Gelsinger et al., 2015) used a large number of calves fed from a single batch of pooled colostrum that had either high or low bacteria levels and was either unheated or heat-treated. Results showed that bacteria were the reason for reduced $\operatorname{IgG}$ absorption in colostrum with high bacterial counts and that the improved IgG absorption from heat-treated colostrum was due to lower bacteria counts rather than 
an intrinsic effect of heat treatment. Additional studies with heat-treated colostrum demonstrated that heat treatment may not increase IgG levels or AEA when initial colostrum quality is very high and bacteria levels are low (Gelsinger and Heinrichs, 2017; Saldana et al., 2019a). A further study also looked at heat treatment and its effects on reducing immunity-related proteins in the young calf (Gelsinger and Heinrichs, 2017). A total of 62 proteins found in colostrum samples differed in abundance by more than 2-fold in heat-treated (for 30,60 , or $90 \mathrm{~min}$ ) samples compared with the unheated control. The majority of proteins affected by heat treatment were involved in immunity, enzyme function, and transport-related processes (Tacoma et al., 2017). Although heat treatment of colostrum is an excellent means to reduce bacteria and increase IgG absorption, it is not without issues that should be understood.

\section{Additives and Colostrum Replacer}

Several studies have evaluated colostrum replacer (CR) feeding and the use of additives to enhance IgG uptake in calves. Shea et al. (2009) evaluated feeding 1 or 2 doses (105 g of IgG/dose) of a lacteal-based $\mathrm{CR}$ with or without supplemental lactoferrin $(\mathbf{L F})$ to 80 Holstein bull calves. Lactoferrin has been shown to improve intestinal development and immunity in mice and humans (Shah, 2000; Zhang et al., 2001). Calves fed 2 doses of $\mathrm{CR}$ had greater serum $\operatorname{IgG}(P=0.005)$ and AEA at $24 \mathrm{~h}(P<0.0001)$. These results were likely due to more $\operatorname{IgG}$ being provided in the 2-dose treatment. Lactoferrin addition resulted in a negative quadratic response for AEA and xylose area under the curve. Xylose absorption tests are a means of determining intestinal development. These data suggest that LF affected intestinal absorption of IgG. A similar study was conducted using maternal colostrum; no benefits of added LF on IgG uptake, AEA, or xylose absorption were observed in that experiment (Connelly and Erickson, 2016). Heating colostrum in the manufacture of CR could have reduced the LF in CR. Paulsson et al. (1993) showed that heating LF from 60 to $100^{\circ} \mathrm{C}$ resulted in 10 to $100 \%$ denaturation of LF.

The diet fed to the prepartum dam can positively or negatively affect colostral IgG and other components in colostrum, along with the ability for the calf to absorb $\mathrm{Ig}$ and nutrients from colostrum. Feeding prepartum cows a negative-DCAD diet may reduce the ability of the calf to absorb IgG (Joyce and Sanchez, 1994). This may be due to the neonate suffering from metabolic acidosis. To test this hypothesis, adding $\mathrm{NaHCO}_{3}$ to $\mathrm{CR}$ was evaluated to determine whether the absorption of IgG was enhanced. Prepartum Holstein cows were placed on diets with a DCAD of $-100 \mathrm{mEq} / \mathrm{kg}$ or +77 $\mathrm{mEq} / \mathrm{kg}$, and calves received lacteal-based CR (198 g of $\mathrm{IgG}$ ) with or without $\mathrm{NaHCO}_{3}$ to increase the $\mathrm{pH}$ of the CR to 7.0. Results indicated that a negative-DCAD diet did not affect IgG absorption, but adding $\mathrm{NaHCO}_{3}$ increased IgG uptake by $23 \%$ (serum IgG of $16 \mathrm{~g} / \mathrm{L}$ vs. $13 \mathrm{~g} / \mathrm{L}$ for treatment and control, respectively; Morrill et al., 2010). To determine the optimum dose of $\mathrm{NaHCO}_{3}$ to add to CR, in a follow-up study 52 calves were fed CR containing $0,15,30$, or $45 \mathrm{~g} / \mathrm{d} \mathrm{NaHCO}_{3}$ (Cabral et al., 2011). Results indicated a tendency for IgG to decrease in plasma IgG as $\mathrm{NaHCO}_{3}$ increased $(P=0.08)$. A linear reduction $(P<0.05)$ in AEA and area under the curve for IgG was observed. The results appeared to be primarily driven by the greatest amount of $\mathrm{NaHCO}_{3}$, possibly indicating metabolic alkalosis in those calves. These results were contrary to the earlier results of Morrill et al. (2010). A major difference between these studies was that Morrill et al. (2010) fed CR in 2 feedings, whereas Cabral et al. (2011) fed CR in a single feeding. Therefore, Cabral et al. (2012) fed $\mathrm{CR}$ in 1 or 2 feedings to 40 calves, with calves receiving either 0 or $30 \mathrm{~g}$ of $\mathrm{NaHCO}_{3}$ in a randomized block design. An interaction for number of feedings and $\mathrm{NaH}-$ $\mathrm{CO}_{3}$ was observed $(P=0.02)$ for 24 -h IgG concentration. Calves fed $\mathrm{CR}$ once with $\mathrm{NaHCO}_{3}$ had $7 \%$ greater IgG compared with calves fed once without $\mathrm{NaHCO}_{3}$. These data indicated that in calves fed a single feeding of $\mathrm{CR}$, supplementing $30 \mathrm{~g}$ of $\mathrm{NaHCO}_{3}$ improved $\mathrm{IgG}$ absorption. In another study to investigate IgG uptake in calves fed $\mathrm{CR}$ with or without $\mathrm{NaHCO}_{3}, 80$ newborn calves were fed $\mathrm{CR}$ once or twice with or without $\mathrm{NaHCO}_{3}$ and milk replacer (MR) in the same day with or without $\mathrm{NaHCO}_{3}$. Results indicated that every calf fed $\mathrm{NaHCO}_{3}$ had reduced blood IgG, possibly due to the dams being fed an alkalotic diet resulting in the calves fed $\mathrm{NaHCO}_{3}$ having metabolic alkalosis (Cabral et al., 2014). Results were similar to an earlier study in which $45 \mathrm{~g}$ of $\mathrm{NaHCO}_{3}$ added to $\mathrm{CR}$ caused a negative linear effect on blood IgG concentration at $24 \mathrm{~h}$ (Cabral et al., 2011).

One study was conducted to evaluate the use of $\mathrm{NaHCO}_{3}$ in maternal colostrum. Results indicated no benefit of adding $30 \mathrm{~g}$ of sodium bicarbonate $(\mathrm{NaH}-$ $\left.\mathrm{CO}_{3}\right)$ to high-quality maternal colostrum $(82.05 \pm 8.45$ $\mathrm{g} / \mathrm{L} \operatorname{IgG}$ ) with regard to IgG uptake or AEA by calves (Chapman et al., 2012).

\section{Influence of the Dam on Colostrum IgG Content}

Other studies attempted to predict colostrum IgG content from information about previous lactation performance and weather (Cabral et al., 2016). Data from 
111 cows from 9 Holstein dairy farms in New Hampshire were used to predict colostrum quality from cows with at least 1 previous lactation. Previous production of milk and components along with component content, SCS, parity, and predicted transmitting abilities from DHI data were used. Weeks on pasture during the dry period, previous lactation fat content, previous lactation total protein yield, and predicted transmitting ability for milk had negative effects on the prediction of colostrum quality, whereas previous lactation fat yield, previous lactation protein content, parity, and days during the $3 \mathrm{wk}$ immediately prepartum with the environmental temperature $>23^{\circ} \mathrm{C}$ had positive effects on the prediction of colostrum quality (Cabral et al., 2016). The model was validated using 27 colostrum samples from 9 dairy farms. Data from DHI, local weather stations, and time from calving to colostrum harvest were collected. All data were subjected to the variance inflation factor assessment (SAS version 9.4; SAS Institute Inc., Cary, NC). For each iteration, the highest value was removed until all variables entering the model were $\leq 10$. It was determined that the best fit was when data were converted to natural logarithms, after which all variables are evaluated using the backward elimination procedure until all remaining variables had $P \leq 0.10$. Results indicated that the model modestly predicted $\left(\mathrm{R}^{2}=0.56\right)$ colostrum IgG concentration.

Additional studies investigated how nutrition of the dam prepartum may affect colostrum quality or IgG absorption by the calf. Nicotinic acid may enhance microbial protein synthesis, which may have positive effects on colostrum quality. Aragona et al. (2016) fed either 0 or $48 \mathrm{~g}$ of nicotinic acid/d to 26 multiparous Holstein cows for 4 wk prepartum and observed similar colostrum yield but about 18\% greater IgG content in colostrum from cows supplemented with nicotinic acid. Another potential strategy to improve colostrum is utilizing probiotics and enzymes during the dry period to increase intake and result in more nutrients available for colostrogenesis. Ort et al. (2018) fed 36 multiparous Holstein cows no additives, a direct-fed microbial (DFM) containing Enterococcus faecium (1.323 billion $\mathrm{cfu} / \mathrm{g})$ and Saccharomyces cerevisiae $(45.4 \mathrm{~g} / \mathrm{d})$, or a combination of DFM, cellulase, and amylase for $3 \mathrm{wk}$ prepartum. Results indicated no benefit on colostrum IgG concentration or yield or any effect on calves fed the colostrum. Colostral fat yield was reduced $(P=$ $0.05)$ for supplemented cows, whereas IgA was reduced for cows fed the DFM $(P=0.04)$. Nicotinic acid supplementation to prepartum cows improved colostrum quality, whereas DFM and enzymes did not affect the colostrum. These studies demonstrate that many additives may not affect colostrum IgG concentration.

\section{Milk Feeding Potentially Affecting Future Production}

Cooperators in the dairy management research project also have researched feeding frequency and the amount fed to calves. In the area of feeding frequency, feeding 2 or 4 times per day was compared using traditional $20 \% \mathrm{CP}, 20 \%$ fat replacers or $26 \% \mathrm{CP}, 18 \%$ fat products (Kmicikewycz et al., 2013). Offering the lowprotein diet at $1.5 \%$ of $\mathrm{BW}$ or the high-protein diet at $2.0 \%$ of BW had no effect on growth or feed efficiency to 42 or 56 d. Using whole-milk diets, Kehoe et al. (2007a) found that starter intake was increased when feeding once versus twice daily for calves weaned at 4,5 , or 6 wk. Body weight and withers height were the same for all groups regardless of weaning age or number of times fed per day with starter and water offered free choice at all times. The same effect of no difference in weight gain or structural growth was observed when Saldana et al. (2019b) fed calves whole milk either once or twice daily at the same rate per day for all calves. These studies show that management changes can be made to minimize labor with no detrimental consequences on calf growth. Frequency of feeding milk or MR was not related to calf grow in any of these studies.

The management question of the amount of liquid feed offered to calves and its effect on future milk production has also been addressed by NC-2042 stations. An early report based primarily on abstracts, meeting proceedings, unpublished data sets, and personal communication (Soberon and Van Amburgh, 2013) led to interesting conclusions and prompted much research in this area. Using 11 peer-reviewed studies, Gelsinger et al. (2016) published a meta-analysis of these experiments. The meta-analysis showed that every $100 \mathrm{~g}$ of gain/d during the preweaning period yields $150 \mathrm{~kg}$ of milk during the first lactation. By accounting for energy and protein intakes from milk or MR and grain, the authors showed that $19.6 \%$ of this first-lactation milk production variation was related to milk feeding amounts and $80.4 \%$ was related to increased grain intakes. However, an important highlight of the study was that ADG during the milk feeding portion of the animal's life accounted for only $2.3 \%$ of the variation in first-lactation milk production. A further large study by Chester-Jones et al. (2017) using 2,880 individual animal observations and milk and grain intakes up to 8 wk also showed small but significant improvements in first-lactation milk, fat, and protein production when calves consumed more energy and protein from grain intake. In another large study, Rauba et al. (2019) collected MR and starter protein intake, ME intake, and growth data from birth to $195 \mathrm{~d}$ for 4,534 Holstein heifer calves born from 2004 to 2014 on 3 commercial 
dairies. First-lactation production data were available for 3,627 of these animals. Protein and ME intake from starter affected growth more than the same nutrients from MR, which was fed at a conventional level for a high percentage of calves. Starter protein and ME intake during the first 6 and 8 wk had a positive relationship with first-lactation 305-d milk, fat, and protein production.

The effect of grain intake on future milk has also been shown in a large management study that looked at calf factors related to 305-d first-lactation production (Heinrichs and Heinrichs, 2011) and showed that health events and grain intake at weaning were the 2 largest calfhood factors related to first-lactation milk production.

Finally, Van De Stroet et al. (2016) summarized a large group of calf studies to look at the effects of young calf growth on production parameters in the first lactation. Results showed that calf growth during the preweaning period was related to future potential. The shortest calves (based on hip height) had lower milk production potential and were most likely to be removed from the herd before first lactation. In addition, weaned calves with medium or tall hip height had a greater potential for milk production than short calves across all lactations.

\section{MR Feeding}

Guindon et al. (2015) studied reducing weaning stress in calves fed a high-protein MR at high levels. Calves were fed either a 20\% CP, 20\% fat MR (454 g of powder/d; 4 L/d; Conv) or a $28 \%$ CP, $20 \%$ fat MR $(916 \mathrm{~g} / \mathrm{d}$ from d 2 to 8 and 1,134 g/d from d 9 to 41; HP). Calves fed HP consumed more MR as expected, more water $(P=0.007)$, and less starter $(P<0.006)$. The HP-fed calves gained more $(P=0.01)$ weight and were more efficient $(P=0.007)$ compared with the Conv calves during the preweaning period. During weaning week, Conv calves consumed more starter $(P$ $=0.003)$ and less MR than HP calves $(P<0.001)$. No other differences were detected among the treatments. The increase in starter intake in the Conv-fed calves continued into the postweaned week $(P=0.08)$. Results of this study indicated that calves fed HP gained at a greater rate, consumed more water, and were more efficient preweaning, but these differences went away during the weaning week and postweaning.

Chapman et al. (2017a) fed calves $446 \mathrm{~g}$ of a $20 \% \mathrm{CP}$, $20 \%$ fat MR (Con), $680 \mathrm{~g} / \mathrm{d}$ of a $26 \% \mathrm{CP}, 18 \%$ fat MR (Mod), or $908 \mathrm{~g} / \mathrm{d}$ of the Mod treatment (AAG). During wh 5 , all calves were fitted with a urinary catheter and urine was collected for $3 \mathrm{~d}$. Simultaneously, nutrient digestibility was determined using chromium oxide as an external marker. As in the study of Guindon et al. (2015), calves responded by consuming less starter as MR increased $(P=0.01)$, and $\mathrm{ADG}(P=0.002)$ and feed efficiency $(P=0.02)$ increased as MR feeding rate increased. Nitrogen efficiency was $15.3 \%$ greater in the Con treatment compared with the other treatments $(P=0.01)$. Calves fed the Mod and AAG treatments produced more urine $(1.13$ and $2.23 \mathrm{~kg} / \mathrm{d}$ more, respectively, than Con calves; $P<0.001)$ and excreted more $\mathrm{N}$ in their urine than Con calves (12.1, 17.0, and 18.2 $\mathrm{g} / \mathrm{d}$ for Con, Mod, and AAG, respectively; $P=0.02$ ). Calves fed the Con program had less percentage $\mathrm{N}$ in their feces than calves fed the AAG treatment $(3.93 \%$ vs. $5.21 \% ; P=0.02)$. Using calves from the same study (Chapman et al., 2017b), on d 50 calves received an intravenous dose of deuterium oxide $(300 \mathrm{mg} / \mathrm{kg}$ ) to develop a new means of determining body composition evaluating the decay of deuterium over the subsequent week and analyzing blood using nuclear magnetic resonance spectroscopy. Results indicated that using nuclear magnetic resonance is a valid method for determining body composition, and there were no differences among treatments with regard to body composition during the last week of the experiment.

\section{Alternative Proteins for MR}

In the past $25 \mathrm{yr}$, as human demand for dairy proteins has created competition for high-quality proteins (Thornsberry et al., 2016), all-milk protein MR formulas have replaced casein or skim milk with whey protein, whey protein concentrate, delactosed whey, or whey protein isolates. The fluctuating costs of MR have increased interest in cheaper alternatives. Other plant and animal protein options include modified wheat such as hydrolyzed wheat gluten protein, blood plasma proteins (PL), egg, and peptide protein powder (PP), although antinutritional factors and lower AA profiles plus decreased digestibility are a concern (Raeth et al., 2016). The NC-2042 group has evaluated many alternative proteins in MR. Thornsberry et al. (2016) summarized alternative protein studies at the University of Minnesota. Many of the studies used a $20 \%$ CP, $20 \%$ fat MR fed at $0.57 \mathrm{~kg} / \mathrm{d}$ for $35 \mathrm{~d}$ and half this amount from d 36 to weaning at $42 \mathrm{~d}$. Studies offered water and $18 \%$ CP (as-fed) calf starter free choice. Typically, up to $50 \%$ of milk proteins were replaced by plant sources. Three University of Minnesota study examples were implemented between 2004 and 2014 (Raeth et al., 2016). The $100 \%$ all-milk protein (20\% CP, $20 \%$ fat) MR was compared with $30 \%$ wheat gluten (WG), $50 \%$ WG, $50 \%$ soy protein concentrate (SPC), and a 1:1 ratio of $50 \%$ WG and SPC. In one study, the alternative protein MR reduced preweaning ADG compared with 
the control. The intake of calf starter was not compromised by MR protein sources. A second study replaced all-milk whey protein concentrate with 50\% WG 1:1 with PL, $50 \%$ SPC and PL, or $50 \%$ from PL, WG, and $\mathrm{SPC}$ and fed as in previous studies. Calf performance across diets was not different. In the third study, whey protein concentrate in MR was partially replaced by $25 \%$ PL, 25\% PP, or 25\% PL and PP. Milk replacer was fed at $0.68 \mathrm{~kg}$ in $4.76 \mathrm{~L}$ of water twice daily for $35 \mathrm{~d}$ and once daily with half the amount from d 36 to 42. No differences occurred across MR treatments with comparable growth and health. Frame growth and mortality standards were met for all MR treatments.

\section{Water Preferences of Young Calves}

A final area of calf management studied has been drinking water preferences by calves. Senevirathne et al. (2016) evaluated the drinking preference of young calves for reverse-osmosis water (RW), municipal city water (MW), or untreated well water. Preference was greatest for RW, with MW a close second. However, a follow-up study comparing RW and MW showed similar health yet less water intake of RW with similar animal growth (Senevirathne et al., 2018).

The work done in colostrum management, heat treatment, and use of supplements and additives has been important and helpful to dairy farmers. Showing that milk feeding amounts and frequency of feeding have minimal effects on first-lactation performance and the importance of grain feeding and MR ingredients is economically valuable for dairy farmers. As new developments in nutrition and management arise, researchers will continue to study best nutrition and management for dairy calves for profitable and environmentally efficient dairy farms.

\section{REFERENCES}

Aragona, K. M., C. E. Chapman, A. B. Pereira, B. J. Isenberg, R. B. Standish, C. J. Maugeri, R. G. Cabral, and P. S. Erickson. 2016. Prepartum supplementation of nicotinic acid: Effects on health of the dam, colostrum quality, and acquisition of immunity in the calf. J. Dairy Sci. 99:3529-3538. https://doi.org/10.3168/jds.2015 -10598 .

Cabral, R. G., M. A. Cabral, C. E. Chapman, E. J. Kent, D. M. Haines, and P. S. Erickson. 2014. Colostrum replacer feeding regimen, addition of sodium bicarbonate, and milk replacer: The combined effects on absorptive efficiency of immunoglobulin $\mathrm{G}$ in neonatal calves. J. Dairy Sci. 97:2291-2296. https://doi.org/10.3168/ jds.2013-7007.

Cabral, R. G., C. E. Chapman, K. M. Aragona, E. Clark, M. Lunak, and P. S. Erickson. 2016. Predicting colostrum quality from performance in the previous lactation and environmental changes. J. Dairy Sci. 99:4048-4055. https://doi.org/10.3168/jds.2015-9868.

Cabral, R. G., C. E. Chapman, D. M. Haines, A. F. Brito, and P. S. Erickson. 2011. Short communication: Addition of varying amounts of sodium bicarbonate to colostrum replacer: Effects on immunoglobulin $\mathrm{G}$ absorption and serum bicarbonate in neonatal calves. J. Dairy Sci. 94:5656-5660. https://doi.org/10.3168/ jds.2011-4235.

Cabral, R. G., E. J. Kent, D. M. Haines, and P. S. Erickson. 2012. Addition of sodium bicarbonate to either 1 or 2 feedings of colostrum replacer: Effect on uptake and rate of absorption of immunoglobulin G in neonatal calves. J. Dairy Sci. 95:3337-3341. https://doi .org/10.3168/jds.2011-5137.

Chapman, C. E., R. G. Cabral, S. P. Marston, A. F. Brito, and P. S. Erickson. 2012. Short communication: Addition of sodium bicarbonate to maternal colostrum: Effects on immunoglobulin G absorption and hematocrit in neonatal calves. J. Dairy Sci. 95:53315335. https://doi.org/10.3168/jds.2011-5184.

Chapman, C. E., T. M. Hill, D. R. Elder, and P. S. Erickson. 2017a. Nitrogen utilization, preweaning nutrient digestibility, and growth effects of Holstein dairy calves fed 2 amounts of a moderately high protein or conventional milk replacer. J. Dairy Sci. 100:279-292. https://doi.org/10.3168/jds.2016-11886.

Chapman, C. E., P. S. Wilkinson, M. R. Murphy, and P. S. Erickson. 2017b. Technical note: Evaluating nuclear magnetic resonance spectroscopy for determining body composition in Holstein dairy calves using deuterium oxide dilution methods. J. Dairy Sci. 100:2807-2811. https://doi.org/10.3168/jds.2016-11888.

Chester-Jones, H., B. J. Heins, D. Ziegler, D. Schimek, S. Schuling, B. Ziegler, M. B. de Ondarza, C. J. Sniffen, and N. Broadwater. 2017. Relationships between early-life growth, intake, and birth season with first-lactation performance of Holstein dairy cows. J. Dairy Sci. 100:3697-3704. https://doi.org/10.3168/jds.2016-12229.

Connelly, R. A., and P. S. Erickson. 2016. Lactoferrin supplementation of the neonatal calf has no impact on immunoglobulin G absorption and intestinal development in the first days of life. J. Anim. Sci. 94:196-200. https://doi.org/10.2527/jas.2015-8918.

Elizondo-Salazar, J. A., and A. J. Heinrichs. 2009a. Feeding heattreated colostrum or unheated colostrum with two different bacterial concentrations to neonatal dairy calves. J. Dairy Sci. 92:45654571. https://doi.org/10.3168/jds.2009-2188.

Elizondo-Salazar, J. A., and A. J. Heinrichs. 2009b. Feeding heattreated colostrum to neonatal dairy heifers: Effects on growth characteristics and blood parameters. J. Dairy Sci. 92:3265-3273. https://doi.org/10.3168/jds.2008-1667.

Elizondo-Salazar, J. A., B. M. Jayarao, and A. J. Heinrichs. 2010. Effect of heat treatment of bovine colostrum on bacterial counts, viscosity, and immunoglobulin G concentration. J. Dairy Sci. 93:961-967. https://doi.org/10.3168/jds.2009-2388.

Foley, J. A., and D. E. Otterby. 1978. Availability, storage, treatment, composition, and feeding value of surplus colostrum: A review. J. Dairy Sci. 61:1033-1060. https://doi.org/10.3168/jds.S0022 -0302(78)83686-8.

Gelsinger, S. L., S. M. Gray, C. M. Jones, and A. J. Heinrichs. 2014 Heat treatment of colostrum increases immunoglobulin G absorption efficiency in high-, medium-, and low-quality colostrum. J. Dairy Sci. 97:2355-2360. https://doi.org/10.3168/jds.2013-7374.

Gelsinger, S. L., and A. J. Heinrichs. 2017. Comparison of immune responses in calves fed heat-treated or unheated colostrum. J. Dairy Sci. 100:4090-4101. https://doi.org/10.3168/jds.2016-12010.

Gelsinger, S. L., A. J. Heinrichs, and C. M. Jones. 2016. A metaanalysis of the effects of preweaned calf nutrition and growth on first-lactation performance. J. Dairy Sci. 99:6206-6214. https:// doi.org/10.3168/jds.2015-10744.

Gelsinger, S. L., C. M. Jones, and A. J. Heinrichs. 2015. Effect of colostrum heat treatment and bacterial population on immunoglobulin G absorption and health of neonatal calves. J. Dairy Sci. 98:4640-4645. https://doi.org/10.3168/jds.2014-8790.

Godden, S., S. McMartin, J. Feirtag, J. Stabel, R. Bey, S. Goyal, L. Metzger, J. Fetrow, S. Wells, and H. Chester-Jones. 2006. Heattreatment of bovine colostrum. II: Effects of heating duration on pathogen viability and immunoglobulin. J. Dairy Sci. 89:34763483. https://doi.org/10.3168/jds.S0022-0302(06)72386-4.

Guindon, N. E., N. T. Antaya, R. G. Cabral, N. L. Whitehouse, T. J. Earleywine, and P. S. Erickson. 2015. Effects of human visitation on calf growth and performance of calves fed different milk re- 
placer feeding levels. J. Dairy Sci. 98:8952-8961. https://doi.org/ $10.3168 /$ jds.2015-9759.

Heinrichs, A. J., and B. S. Heinrichs. 2011. A prospective study of calf factors affecting first-lactation and lifetime milk production and age of cows when removed from the herd. J. Dairy Sci. 94:336-341. https://doi.org/10.3168/jds.2010-3170.

Houser, B. A., S. C. Donaldson, S. I. Kehoe, A. J. Heinrichs, and B. M. Jayarao. 2008. A survey of bacteriological quality and the occurrence of Salmonella in raw bovine colostrum. Foodborne Pathog. Dis. 5:853-858. https://doi.org/10.1089/fpd.2008.0141.

Joyce, P. W., and W. K. Sanchez. 1994. Dietary cation-anion difference and forage type during the dry period: Effect on lactational performance and metabolic disorders of cows and health of calves. J. Dairy Sci. 77(Suppl. 1):97. (Abstr.)

Kehoe, S. I., C. D. Dechow, and A. J. Heinrichs. 2007a. Effects of weaning age and milk feeding frequency on dairy calf growth, health, and rumen parameters. Livest. Sci. 110:267-272. https:// doi.org/10.1016/j.livsci.2006.11.007.

Kehoe, S. I., B. M. Jayarao, and A. J. Heinrichs. 2007b. A survey of bovine colostrum composition and colostrum management practices on Pennsylvania dairy farms. J. Dairy Sci. 90:4108-4116. https: //doi.org/10.3168/jds.2007-0040.

Kmicikewycz, A. D., D. N. da Silva, J. G. Linn, and N. B. Litherland. 2013. Effects of milk replacer program fed 2 or 4 times daily on nutrient intake and calf growth. J. Dairy Sci. 96:1125-1134. https: //doi.org/10.3168/jds.2012-5738.

Morrill, K. M., S. P. Marston, N. L. Whitehouse, M. E. Van Amburgh, C. G. Schwab, D. M. Haines, and P. S. Erickson. 2010. Anionic salts in the prepartum diet and addition of sodium bicarbonate to colostrum replacer, and their effects on immunoglobulin G absorption in the neonate. J. Dairy Sci. 93:2067-2075. https://doi.org/10 $.3168 /$ jds.2009-2622.

Ort, S. B., K. M. Aragona, C. E. Chapman, E. Shangraw, A. F. Brito, D. J. Schauff, and P. S. Erickson. 2018. The impact of direct-fed microbials and enzymes on the health and performance of dairy cows with emphasis on colostrum quality and serum immunoglobulin concentrations in calves. J. Anim. Physiol. Anim. Nutr. (Berl.) 102:e641-e652. https://doi.org/10.1111/jpn.12806.

Paulsson, M. A., U. Svensson, A. R. Kishore, and A. S. Naidu. 1993. Thermal behavior of bovine lactoferrin in water and its relation to bacterial interaction and antibacterial activity. J. Dairy Sci. 76:3711-3720. https://doi.org/10.3168/jds.S0022-0302(93)77713 -9 .

Raeth, M., H. Chester-Jones, D. Ziegler, B. Ziegler, D. Schimek, D. L. Cook, G. Golombeski, and A. V. Grove. 2016. Pre- and postweaning performance and health of dairy calves fed milk replacers with differing protein sources. Prof. Anim. Sci. 32:833-841. https://doi .org/10.15232/pas.2016-01536.

Rauba, J., B. J. Heins, H. Chester-Jones, H. L. Diaz, D. Ziegler, J. Linn, and N. Broadwater. 2019. Relationships between protein and energy consumed from milk replacer and starter and calf growth and first-lactation production of Holstein dairy cows. J. Dairy Sci. 102:301-310. https://doi.org/10.3168/jds.2018-15074.

Saldana, D. J., S. L. Gelsinger, C. M. Jones, and A. J. Heinrichs. 2019a. Effect of different heating times of high-, medium-, and low-quality colostrum on immunoglobulin G absorption in dairy calves. J. Dairy Sci. 102:2068-2074. https://doi.org/10.3168/jds 2018-15542.

Saldana, D. J., C. M. Jones, A. M. Gehman, and A. J. Heinrichs. 2019b. Effects of once- versus twice-a-day feeding of pasteurized milk supplemented with yeast-derived feed additives on growth and health in female dairy calves. J. Dairy Sci. 102:3654-3660. https://doi.org/10.3168/jds.2018-15695.

Senevirathne, N. D., J. L. Anderson, and M. Rovai. 2016. Effect of water treatment on drinking preferences of dairy heifers. Accessed Jul. 30, 2019. https://asas.confex.com/asas/mw16/webprogram/ Paper13344.html.

Senevirathne, N. D., J. L. Anderson, and M. Rovai. 2018. Growth performance and health of dairy calves given water treated with a reverse osmosis system compared with municipal city water. J. Dairy Sci. 101:8890-8901. https://doi.org/10.3168/jds.2018-14800.

Shah, N. P. 2000. Effects of milk derived bioactives: An overview. Br. J. Nutr. 84(Suppl. 1):S3-S10. https://doi.org/10.1017/ s000711450000218x.

Shea, E. C., N. L. Whitehouse, and P. S. Erickson. 2009. Effects of colostrum replacer supplemented with lactoferrin on the blood plasma immunoglobulin $\mathrm{G}$ concentration and intestinal absorption of xylose in the neonatal calf. J. Anim. Sci. 87:2047-2054. https:/ /doi.org/10.2527/jas.2008-1225.

Soberon, F., and M. E. Van Amburgh. 2013. Lactation Biology Symposium: The effect of nutrient intake from milk or milk replacer of preweaned dairy calves on lactation milk yield as adults: A meta-analysis of current data. J. Anim. Sci. 91:706-712. https:// doi.org/10.2527/jas.2012-5834.

Tacoma, R., S. L. Gelsinger, Y. W. Lam, R. A. Scuderi, D. B. Ebenstein, A. J. Heinrichs, and S. L. Greenwood. 2017. Exploration of the bovine colostrum proteome and effects of heat treatment time on colostrum protein profile. J. Dairy Sci. 100:9392-9401. https:// doi.org/10.3168/jds.2017-13211.

Thornsberry, R. M., D. S. Wood, A. F. Kertz, and D. Hutchinson. 2016. Alternative ingredients in calf milk replacers-A review for bovine practitioners. Bov. Pract. 50:65-88.

Van De Stroet, D. L., J. A. Calderon Diaz, K. J. Stalder, A. J. Heinrichs, and C. D. Dechow. 2016. Association of calf growth traits with production characteristics in dairy cattle. J. Dairy Sci. 99:8347-8355. https://doi.org/10.3168/jds.2015-10738.

Zhang, P., V. Sawicki, A. Lewis, L. Hanson, J. H. Nuijens, and M. C. Neville. 2001. Human lactoferrin in the milk of transgenic mice increases intestinal growth in ten-day-old suckling neonates. Adv. Exp. Med. Biol. 501:107-113. https://doi.org/10.1007/978-1-4615 -1371-1_13.

\section{ORCIDS}

A. J. Heinrichs @ (ํ) https://orcid.org/0000-0001-5217-473X

C. M. Jones (ㄴ) https://orcid.org/0000-0002-3444-6110

P. S. Erickson ๑ https://orcid.org/0000-0002-8028-3279

H. Chester-Jones $\odot$ https://orcid.org/0000-0002-0619-4091

J. L. Anderson () https://orcid.org/0000-0001-7590-0749 